\title{
Deep Purification Technogenic Solutions of Nickel Ions (II) by the Modified Aluminosilicate
}

\author{
Olga I. Pomazkina, Elena G. Filatova, \\ Oksana V. Lebedeva and Yury N. Pozhidaev* \\ National Research Irkutsk State Technical University \\ 83 Lermontov Str., Irkutsk, 664074, Russia
}

Received 10.01.2017, received in revised form 13.02.2017, accepted 19.03.2017

There studied an adsorption method for purifying technological solutions of nickel (II) ions modified aluminosilicates. The obtained adsorption isotherms. Experimental data were processed using the models of Langmuir, Freundlich, BET and Dubinin-Radushkevich. Defined constants for these equations. It is shown that the adsorption on aluminosilicates modified poly-1-vinylimidazole best describes the model of Freundlich the adsorption on aluminosilicates modified poly-4vinylpyridine - Langmuir. The model of Dubinin-Radushkevich is used to calculate the free energy of adsorption. For all modified aluminosilicates, the value of free energy of adsorption, indicates an ion exchange mechanism, and fixation the ions of Nickel (II) has a chemical nature.

Keywords: deep water purification, adsorption, modified aluminosilicates, nickel ion (II).

Citation: Pomazkina O.I., Filatova E.G., Lebedeva O.V., Pozhidaev Yu.N. Deep purification technogenic solutions of nickel ions (II) by the modified aluminosilicate, J. Sib. Fed. Univ. Eng. technol., 2017, 10(3), 327-336. DOI: 10.17516/1999-494X-201710-3-327-336.

(C) Siberian Federal University. All rights reserved

* Corresponding author E-mail address: efila@list.ru,olga_pomazkina@mail.ru 


\title{
Глубокая доочистка техногенных растворов \\ от ионов никеля (II) \\ модифицированными алюмосиликатами
}

\author{
О.И. Помазкина, Е.Г. Филатова, \\ О.В. Лебедева, Ю.Н. Пожидаев \\ Иркутский национальный исследовательский \\ технический университет \\ Россия, 664074, Иркутск, ул. Лермонтова, 83
}

Изучен адсорбционный способ очистки техногенных растворов от ионов никеля (II) модифицированными алюмосиликатами. Получены изотермы адсорбиии. Экспериментальные данные обработаны с применением моделей Ленгмюра, Фрейндлиха, БЭТ и ДубининаРадушкевича. Определень константы этих уравнений. Показано, что адсорбцию на алюмосиликатах, модифицированных поли-1-винилимидазолом, наилучиим образом описывает модель адсорбции Фрейндлиха, на алюмосиликатах, модифицированных поли4-винилпиридином - Ленгмюра. Модель Дубинина-Радушкевича использована для расчета свободной энергии адсорбиии. Для всех модифицированных алюмосиликатов значение свободной энергии адсорбиии указывают на ионообменный механизм, а закрепление ионов никеля (II) имеет химическую природу.

Ключевые слова: глубокая доочистка воды, адсорбция, модифицированные алюмосиликаты, ионы никеля (II).

\section{Introduction}

Natural aluminosilicates characterized by high adsorption properties in relation to ions of metals, is widely used in wastewater treatment. One of the most common natural aluminosilicate is clinoptilolite. It exchanges the capacity that y reaches $2,64 \mathrm{mEg} / \mathrm{g}$ [1]. It is known that in the case of adsorption of ions of divalent metals with the clinoptilolite, as well as other types of aluminosilicates [2], the maximum values of exchange capacity are not achieved. So, the value of the exchange capacity of heulandite is of $1,47 \mathrm{mEg} / \mathrm{g}$ [3]. When the ion adsorption $\mathrm{Sr}$ (II) natural heulandite value exchange capacity was 3,14-6,22 mg/g depending on the initial metal concentration $10-1000 \mathrm{mg} / \mathrm{dm}^{3}$ [4].

The ion exchange capacity of the aluminosilicate is one of the main parameters that characterize their adsorption and technological properties. The amount of adsorption of metal ions can be significantly increased by means of the modification of aluminosilicates.

When extracting ions Ni (II) from aqueous solutions by Serbian clinoptilolite from deposits, the exchange capacity of aluminosilicate increases with an increase in temperature from $1,9 \mathrm{mg} / \mathrm{g}$ at 298 $\mathrm{K}$ to $3,8 \mathrm{mg} / \mathrm{g} 319 \mathrm{~K}$ [5]. In [6], the amount of adsorption of the ions $\mathrm{Ni}$ (II) from aqueous solutions enriched the finely divided clinoptilolite being about $13,03 \mathrm{mg} / \mathrm{g}$. When clinoptilolite modification with chitosan, the amount of adsorption of the ions $\mathrm{Ni}$ (II) significantly increases and reaches $247 \mathrm{mg} / \mathrm{g}$ [7].

It is known that the standards of maximum permissible concentrations of pollutants in effluents from year to year is reduced, therefore, it is necessary to produce the most complete removal of heavy metal ions. 
The purpose of this work is to study the possible extraction of ions $\mathrm{Ni}$ (II) from aqueous solutions using modified aluminosilicates Eastern Transbaikalia.

\section{Experiment}

As object of research there used natural aluminosilicates Eastern Transbaikalia. In the experiments there used the pre-screened on a sieve fraction size of $1,0 \mathrm{~mm}$. Polymers for modification of natural aluminosilicate: poly-1-vinylimidazole (PVIM) and poly-4-vinylpyridine (PVP) were received with binary radical polymerization according to the method [8]. To $1 \mathrm{~g}$ of the aluminosilicate was added $1 \mathrm{~g}$ of polymer, $18 \mathrm{ml}$ of ethanol. The resulting mixture was stirred for 6 hours at $20^{\circ} \mathrm{C}$ on an electromagnetic stirrer. After this time the aluminosilicate was separated from the solution by filtration, washed with water and ethanol, dried oven dried at $100{ }^{\circ} \mathrm{C}$ for 2 hours. The resulting product was weighed, the weight gain was calculated. In the process of modifying a polymer consolidation occurs on the surface of the aluminosilicate.

The presence of characteristic of natural and modified aluminosilicate structural groups was confirmed by IR spectroscopy. IR spectra were obtained on a spectrophotometer "Specord 75IR".

In the IR spectra of modified aluminosilicates manifested intense absorption bands in the region 794 and $727 \mathrm{~cm}^{-1}$, characteristic for stretching vibrations of when Al-O. The intense absorption band of $1040 \mathrm{~cm}^{-1}$ corresponds to asymmetric stretching vibrations of the relations $\mathrm{Si}-\mathrm{O}-\mathrm{Si}$. The absorption band of $3441 \mathrm{~cm}^{-1}$ confirms the presence of communications $\mathrm{O}-\mathrm{H}$. There is a shift characteristic absorption bands of the pyridine nitrogen atom in the high frequency region from 1596 to $1601 \mathrm{~cm}^{-1}$, azole cycle from 1508 to $1497 \mathrm{~cm}^{-1}$.

The study of adsorptive properties of the modified aluminosilicate in relation to the heavy metal ions was carried out on the model solutions prepared from reagents qualification "chemically pure": NiSO4.7H2O; and distillized led water.

Selecting the the initial concentration of model solutions substantiated the real composition of industrial waste water. The content of nickel ion (II) in solution determined the by standard techniques $[9,10]$.

The absorption capacity under study aluminosilicates was studied by static method. In the method of the batches of constant $(1 \mathrm{~g})$ and varying concentrations (from 5 to $200 \mathrm{mg} / \mathrm{l}$ ). The investigated solutions were prepared $100 \mathrm{ml}$. The mass ratio of liquid and solid phases was 1:100. The amount of adsorption ( $\mathrm{mmol} / \mathrm{g})$ was calculated by the formula:

$$
\mathrm{A}=\frac{\mathrm{C}_{0}-\mathrm{C}_{\mathrm{ecu}}}{\mathrm{m}} \cdot \mathrm{V}
$$

where $\mathrm{C}_{0}$ and $\mathrm{C}_{\text {equ. }}$ - the source metal and the equilibrium concentration in the solution, $\mathrm{mmol} / \mathrm{l} ; \mathrm{V}$ - the volume of solution $1 ; \mathrm{m}-$ mass of sorbent of $\mathrm{g}$.

\section{Results and discussion}

Assessment of the adsorption capacity of modified aluminosilicates in relation to ions of Nickel (II) was carried out on the basis of the analysis of adsorption isotherms. Adsorption equilibrium time corresponding to the constancy of the concentration of nickel (II) in solution was 2 hour. The obtained isotherms are shown in Fig. 1. 
As it can be seen from the presented data (Fig. 1), the maximum value of adsorption in the region of low concentrations are aluminosilicates modified with PVP. The average value of adsorption when the modification is increased 3 times and reached $17 \mathrm{mg} / \mathrm{g}$.

It is known that equilibrium in the adsorption system depends on the nature of interaction between adsorbent-adsorbate [11]. Model of adsorption of Langmuir, Freundlich, BET, Dubinin-Radushkevich and others describe these interactions in different ways [12]. So elucidation was the possible applicability of the mentioned models in the interpretation of experimental results.

Thus, the Langmuir isotherm equation has the form

$$
\mathrm{A}=\mathrm{A}_{\infty} \frac{\mathrm{K} \cdot \mathrm{C}_{\text {ecu. }}}{1+\mathrm{K} \cdot \mathrm{C}_{\text {ecu. }}}
$$

where $\mathrm{A}$ - the current value adsorption $\mathrm{mmol} / \mathrm{g} ; \mathrm{A}_{\infty}$ - maximum amount of adsorption, $\mathrm{mmol} / \mathrm{g}$; $\mathrm{K}$ - constant of adsorption equilibrium; $\mathrm{C}_{\text {ecu }}$ - equilibrium concentration of heavy metal ions, $\mathrm{mmol} / \mathrm{dm}^{3}$.

The obtained experimental results were processed using the Langmuir equation, given in linear form:

$$
\frac{1}{\mathrm{~A}}=\frac{1}{\mathrm{~A}_{\infty}}+\frac{1}{\mathrm{~A}_{\infty} \mathrm{K}} \cdot \frac{1}{\mathrm{C}_{\text {ecu. }}}
$$

The results are presented in Fig. 2.

From graphic linear dependency (Fig. 2). The largest segment of the line that intersects with the ordinate axis, the marginal value of adsorption $\mathrm{A}_{\infty}$, and the slope of the line - adsorption equilibrium constant of the $\mathrm{K}$, the values of which are presented in Table 1.

From the above data (Table 1) shows that the maximum value of the marginal quantities the adsorption characteristic for aluminosilicates modified PVIM. The obtained equations allow to calculate the amount of adsorption of nickel (II) ions modified by adsorbents.

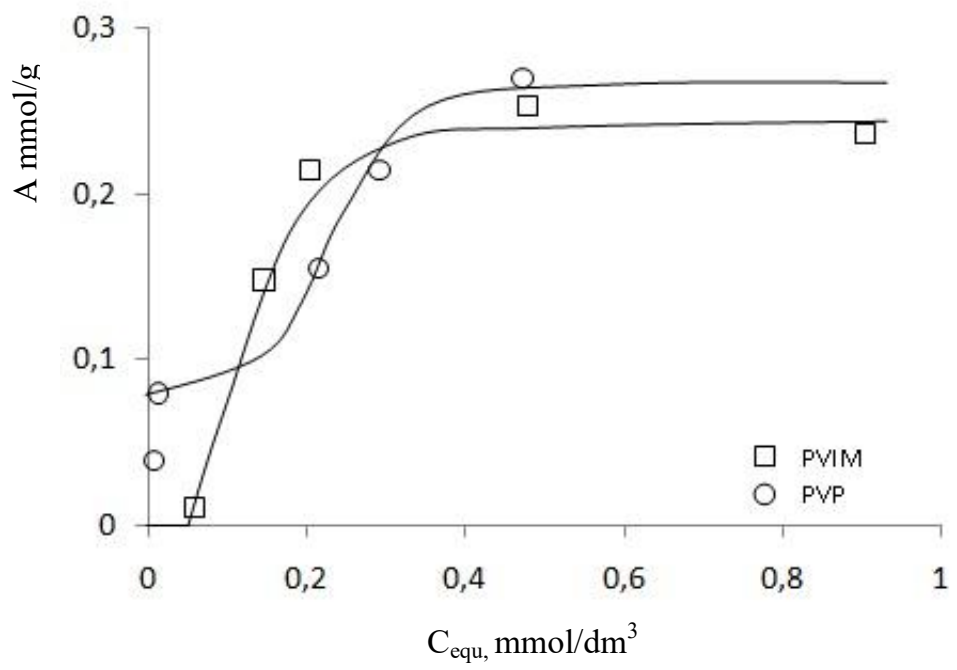

Fig. 1. The adsorption isotherms 


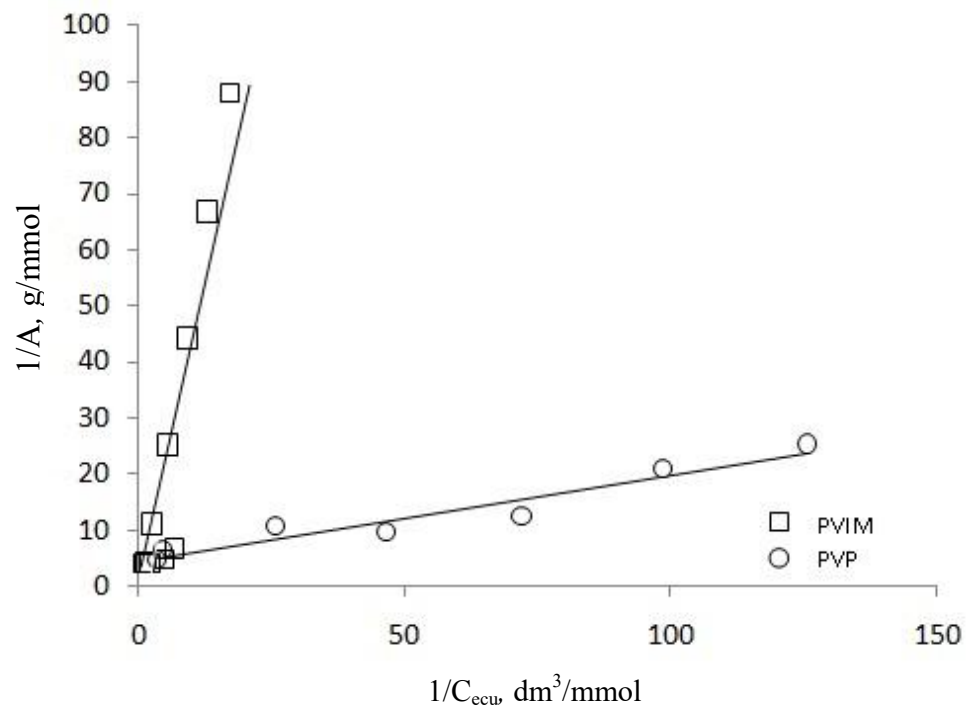

Fig. 2. The adsorption isotherm in coordinates linear form of the Langmuir equation

Table 1. Parameters of the Langmuir model

\begin{tabular}{|c|c|c|c|c|c|}
\hline Modifiers & $\begin{array}{c}\mathrm{A}_{\infty}, \\
\mathrm{mmol} / \mathrm{g}\end{array}$ & $\begin{array}{c}\mathrm{A}_{\infty}, \\
\mathrm{mg} / \mathrm{g}\end{array}$ & $\mathrm{K}$ & The linear form of the Langmuir equation & $\mathrm{R}^{2}$ \\
\hline PVIM & 0,289 & 17,023 & 8,693 & $1 / \mathrm{A}=0,3987 \cdot 1 / \mathrm{C}_{\mathrm{ecu}}+3,466$ & 0,689 \\
\hline PVP & 0,251 & 14,820 & 25,165 & $1 / \mathrm{A}=0,1582 \cdot 1 / \mathrm{C}_{\mathrm{ecu}}+3,9811$ & 0,956 \\
\hline
\end{tabular}

It is known that in the inhomogeneous medium filling the adsorbent surface are widely used empirical Freundlich equation [12]:

$$
A=K_{f} \cdot C_{\text {ecu. }}^{\frac{1}{n}},
$$

where A - adsorption quantity $\mathrm{mmol} / \mathrm{g} ; \mathrm{C}_{\text {ecu }}$ - equilibrium concentration of heavy metal ions, $\mathrm{mmol} / \mathrm{dm}^{3} ; \mathrm{K}_{\mathrm{f}}$ and $\mathrm{n}-$ constants. Most use the Freundlich equation in logarithmic form:

$$
\lg \mathrm{A}=\lg \mathrm{K}_{\mathrm{f}}+1 / \mathrm{n} \cdot \lg \mathrm{C}_{\mathrm{ecu}}
$$

To investigated the modified aluminosilicates constructed according to the linear Freundlich equation logarithmic form (Fig. 3) from which the constant $\mathrm{K}_{\mathrm{f}}$ and $\mathrm{n}$ (Table 2) are defined.

Adsorption centers Freundlich models have different energy values, and above all there is a filling of active adsorption centers with maximum energy. The constants $\mathrm{Kf}$ and $\mathrm{n}$ enable the comparison of the adsorption capacity of the modified aluminosilicate. When the concentration of the nickel ion (II) in a solution of $1 \mathrm{~mol} / \mathrm{l}$ of the adsorption of the ions is equal to a constant $\mathrm{Kf}$, and the parameter $\mathrm{n}$ indicates the intensity of adsorbent-adsorbate interactions. Thus, the nickel ion adsorption (II) on silica-alumina modified PVIM flows faster in the initial period of time, and in the case of the adsorbent, modified PVP is most intensive interaction adsorbent nickel ion (II). 
$\lg \mathrm{A}$

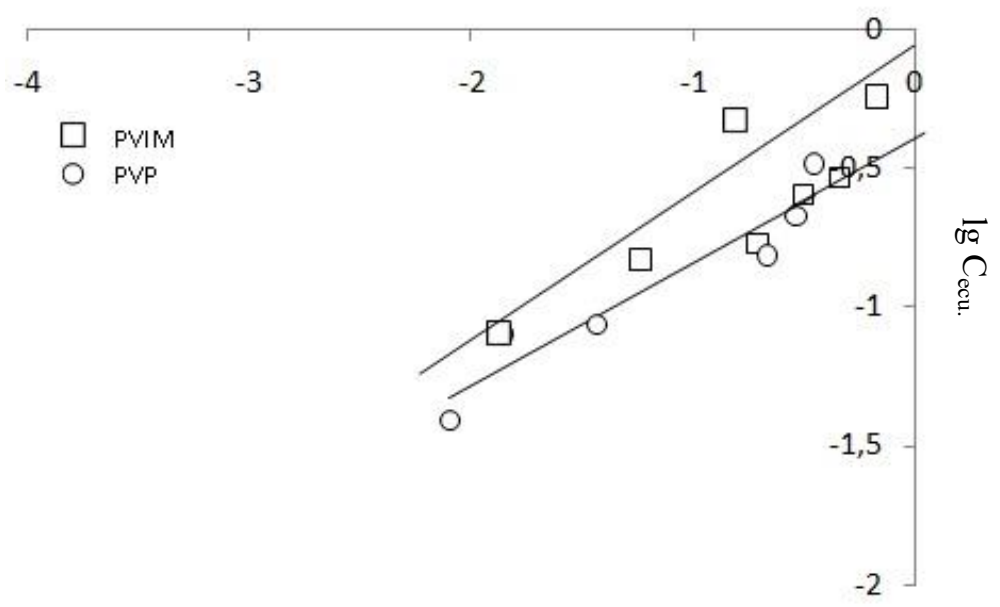

Fig. 3. The adsorption isotherm in coordinates linear form of Freundlich equation

Table 2. The model parameters Freundlich

\begin{tabular}{|c|c|c|c|c|}
\hline Modifiers & The linear form of the Freundlich equation & $\mathrm{K}_{\mathrm{f}}$ & $\mathrm{n}$ & $\mathrm{R}$ \\
\hline PVIM & $\lg \mathrm{A}=-0,039+1,444 \cdot \lg \mathrm{C}_{\text {ecu. }}$ & 0,915 & 0,692 & 0,945 \\
\hline PVP & $\lg \mathrm{A}=-0,400+0,440 \cdot \lg \mathrm{C}_{\text {ecu. }}$ & 0,398 & 2,270 & 0,906 \\
\hline
\end{tabular}

For a description of all types of adsorption isotherms using the BET theory. The equation of the isotherm multilayer adsorption BET:

$$
\mathrm{A}=\frac{\mathrm{A}_{\infty} \cdot \mathrm{c} \cdot\left(\mathrm{C} / \mathrm{C}_{0}\right)}{\left(1-\mathrm{C} / \mathrm{C}_{0}\right) \cdot\left[1+(\mathrm{c}-1)\left(\mathrm{C} / \mathrm{C}_{0}\right)\right]},
$$

where A - adsorption quantity $\mathrm{mmol} / \mathrm{g} ; \mathrm{A}_{\infty}$ - limiting monolayer adsorption capacity $\mathrm{mmol} / \mathrm{g}$; $\mathrm{c}$ - constant for a given adsorption system is directly related to the heat and entropy of adsorption; $\mathrm{C}, \mathrm{C}_{0}$ - equilibrium and the initial concentration of heavy metal ions, $\mathrm{mmol} / \mathrm{dm}^{3}$.

Adsorption BET equation in a linear form:

$$
\frac{\mathrm{C} / \mathrm{C}_{0}}{\mathrm{~A}\left(1-\mathrm{C} / \mathrm{C}_{0}\right)}=\frac{1}{\mathrm{~A}_{\infty} \cdot \mathrm{c}}+\frac{\mathrm{c}-1}{\mathrm{~A}_{\infty} \cdot \mathrm{c}} \cdot \mathrm{C} / \mathrm{C}_{0}
$$

Using the equation of BET adsorption in linear form, built adsorption isotherms for the studied aluminosilicates (Fig. 4).

From linear dependencies shown in Fig. 4, the tangent of the angle of inclination of the straight and the size of the segments, direct intercept with the ordinate axis, determine the limiting adsorption capacity of monolayer $\mathrm{A}_{\infty}$ and c (tabl. 3).

The maximum value of the monolayer adsorption capacity characteristic of aluminosilicates modified with PVP. Due to the fact that the constant $\mathrm{c}$ in the equation is a ratio of BET two equilibrium 


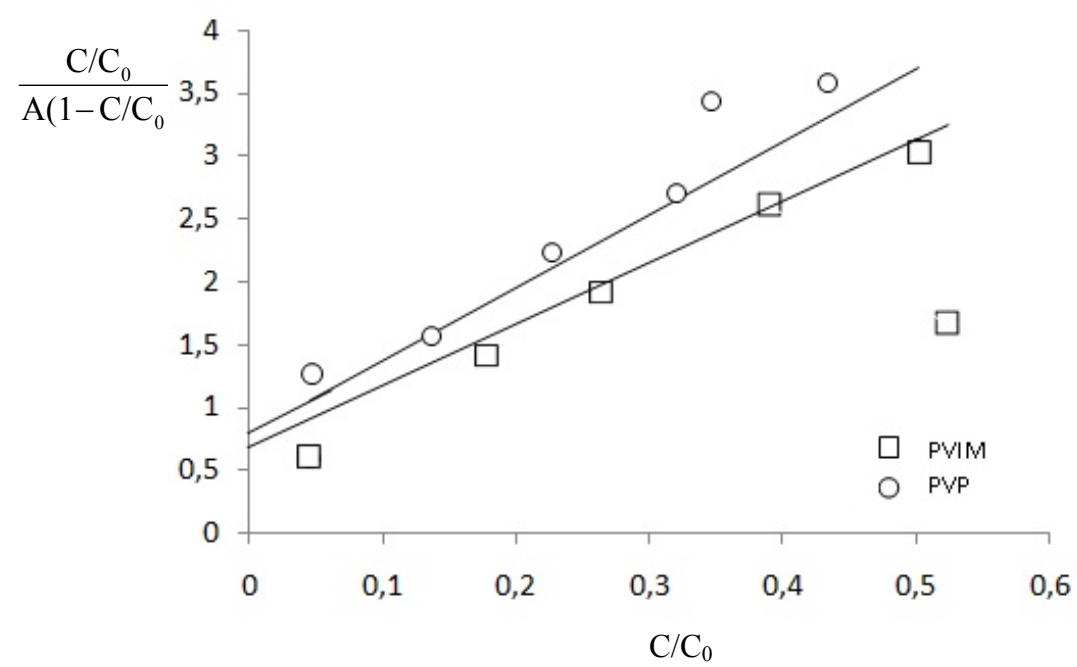

Fig. 4. Adsorption isotherms in coordinates the linear form of the equation BET

Table 3. Parameters BET model

\begin{tabular}{|c|c|c|c|c|}
\hline Modifiers & The linear form BET equation & $\begin{array}{c}\mathrm{A}_{\infty}, \\
\mathrm{mmol} / \mathrm{g}\end{array}$ & $\mathrm{c} \cdot 10^{-3}$ & $\mathrm{R}$ \\
\hline PVIM & $\frac{\mathrm{C} / \mathrm{C}_{0}}{\mathrm{~A}\left(1-\mathrm{C} / \mathrm{C}_{0}\right)}=24,010\left(\mathrm{C} / \mathrm{C}_{0}\right)+0,678$ & 0,041 & 36,413 & 0,868 \\
\hline PVP & $\frac{\mathrm{C} / \mathrm{C}_{0}}{\mathrm{~A}\left(1-\mathrm{C} / \mathrm{C}_{0}\right)}=5,816\left(\mathrm{C} / \mathrm{C}_{0}\right)+0,789$ & 0,151 & 8,371 & 0,846 \\
\hline
\end{tabular}

constants $\mathrm{c}=\mathrm{k}_{1} / \mathrm{k}_{2}$, it can also be considered the equilibrium constant, i.e. to calculate the standard Gibbs energy there can be used: $\Delta \mathrm{G}{ }^{\circ} \mathrm{C}=-\mathrm{R} \cdot \mathrm{T} \cdot \ln \mathrm{c}=-\mathrm{R} \cdot \mathrm{T} \cdot \ln \mathrm{k}_{1} / \mathrm{k}_{2}$.

The equilibrium adsorption process data were processed using a model isotherm DubininRadushkevich

$$
\mathrm{A}=\mathrm{A}_{\mathrm{m}} \cdot \exp \left(-\mathrm{k} \cdot \varepsilon^{2}\right)
$$

where $\mathrm{k}$ - constant $\left(\mathrm{mol}^{2} / \mathrm{kJ}^{2}\right)$ associated with the adsorption energy; $\varepsilon$ - Polyani potential $(\mathrm{kJ} / \mathrm{mol})$ showing the isothermal operation of transfer mole of nickel ion (II) from the equilibrium volume of the solution to the adsorbent surface and defined by the expression.

$$
\varepsilon=\mathrm{RT} \ln (1+1 / \mathrm{C}),
$$

where $\mathrm{R}$ - universal gas constant, $\mathrm{kJ} / \mathrm{mol} \cdot \mathrm{K} ; \mathrm{T}$ - absolute temperature, $\mathrm{K}$.

Dubinin-Radushkevich equation (7) in logarithmic form:

$$
\ln A=\ln A_{m}-k \cdot \varepsilon^{2} .
$$

Using the equation of adsorption Dubinin-Radushkevich in a linear form, are built according to $\ln A=f(\varepsilon 2)$ (Fig. 5). 


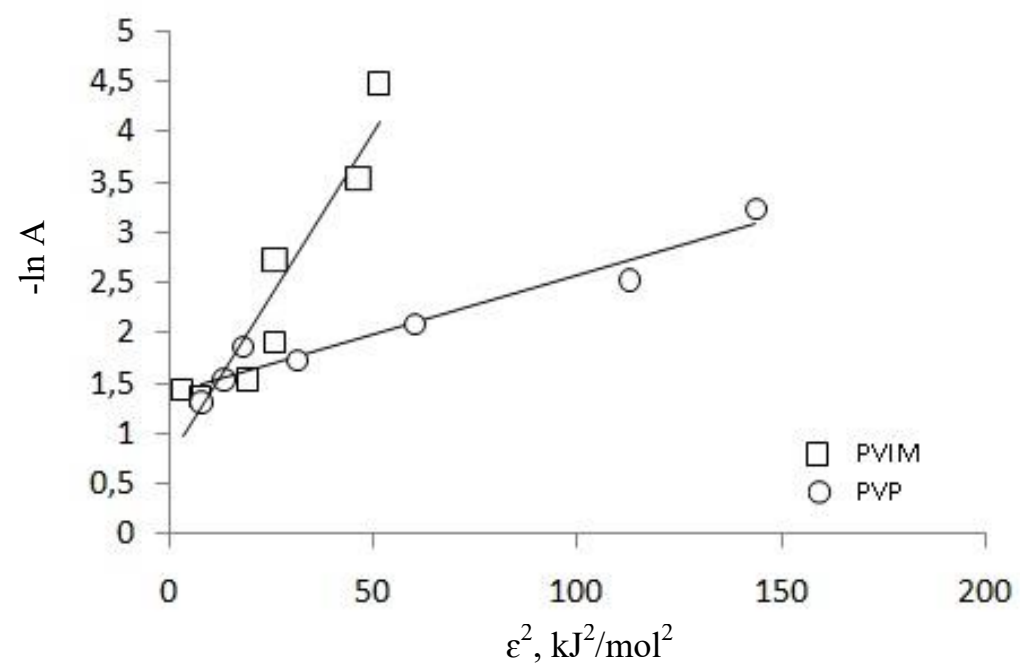

Fig. 5. Adsorption isotherms in coordinates the linear form of the equation of Dubinin-Radushkevich

Table 4. The parameters of the model Dubinin-Radushkevich

\begin{tabular}{|c|c|c|c|c|c|}
\hline Modifiers & $\begin{array}{c}\text { The linear form of equation } \\
\text { Dubinin-Radushkevich }\end{array}$ & $\begin{array}{c}\mathrm{A}_{\mathrm{m}} \\
\mathrm{mmol} / \mathrm{g}\end{array}$ & $\begin{array}{c}\mathrm{k}, \\
\mathrm{mol}^{2} / \mathrm{kJ}^{2}\end{array}$ & $\begin{array}{c}\mathrm{E}, \\
\mathrm{kJ} / \mathrm{mol}\end{array}$ & $\mathrm{R}$ \\
\hline PVIM & $-\ln \mathrm{A}=-0,745+0,045 \varepsilon^{2}$ & 0,475 & 0,0045 & 10,54 & 0,874 \\
\hline PVP & $-\ln \mathrm{A}=-1,393+0,012 \varepsilon^{2}$ & 0,248 & 0,0019 & 16,22 & 0,936 \\
\hline
\end{tabular}

The slope of the represented straight segment and the intercept on the ordinate was determined constants $\mathrm{k}$ and Am. The model of Dubinin-Radushkevich indicates the nature of adsorption of the adsorbate on the adsorbent and can be used to calculate the free energy of adsorption:

$$
\mathrm{E}=(-2 \mathrm{k})^{-0,5}
$$

The results are shown in Table 4.

It is known that if the value of $\mathrm{E}$ is between 8 and $16 \mathrm{~kJ} / \mathrm{mol}$, the adsorption process takes place by ion exchange mechanism; if the value of $\mathrm{E}$ is less than $8 \mathrm{~kJ} / \mathrm{mol}$, the adsorption process is physical. In this case, for all modified aluminosilicates value of the free energy of adsorption, ion exchange mechanism at the point, and fixing of nickel ions (II) has the chemical nature of the [13-15].

From the analysis of the correlation coefficient values (Table 1-4) represented the Langmuir model, Freundlich, BET, Dubinin-Radushkevicht follows that the adsorption on aluminosilicates modified PVIM best describes the model of Freundlich adsorption on aluminosilicates modified PVP Langmuir model.

At the modifying PVIM greatest convergence of results is obtained using the Freundlich equation. In the latter case, the modification of aluminosilicates PVP adsorption process best describe the adsorption model of Langmuir and Dubinin-Radushkevich. 


\section{Conclusions}

1. Process of adsorption of ions of nickel (II) on the modified aluminosilicates is investigated, adsorption isotherms are constructed.

2. The obtained experimental datas are processed with application of models of Lengmyur, Friendlich, BET, Dubinin-Radushkevich. Constants of these equations are defined. It is shown that adsorption on aluminosilicates of the modified PVIM is in the best way described by model of adsorption of Friendlich, on aluminosilicates of the modified PVP - Lengmyur's model.

3. Dubinin-Radushkevich's model is used for calculation of the free energy of adsorption. For all modified aluminosilicates, value of the free energy of adsorption, point to the ion-exchange mechanism, and fixing of ions of nickel (II) has the chemical nature.

\section{References}

[1] Брек. Д. Цеолитовые молекулярные сита. М.: Мир, 1976. 781 с. [Brek. D. Zeolitic molecular sieves. Moscow, Mir, 1976, 781 p. (in Russian)]

[2] Жданов С.П., Егорова Е.Н. Химия цеолитов. Л.: Наука, 1968. 158 с. [Zhdanov S.P., Egorova E.N. Himiya of zeolites. Leningrad, Nauka, 1968, 158 p. (in Russian)]

[3] Химия цеолитов и катализ на цеолитах. Под ред. Дж. Рабо, М.: Мир, 1980. Т. 1.506 с.; T. 2.422 c. [Chemistry of zeolites and catalysis on zeolites. Pod red. Dzh. Rabo. Moscow, Mir, 1980, V. 1.506 p.; V. 2. 422 p. (in Russian)]

[4] Orechovska J., Misaelides P., Godelitsas A., Rajec P., Klewe-Nebenius H., Noli F., Pavlidou E. Investigation of HEU-type zeolite crystals after interaction with $\mathrm{Sr}^{2+}$ cations in aqueous solution using nuclear and surface analytical techniques, Journal of Radioanalytical and Nuclear Chemistry, 1999, 241(3), 519-527.

[5] Rajic N., Stojakovic D., Jovanovic M., Zabukovec Logar N., Mazaj. M., Kaucic V. Removal of nickel(II) ions from aqueous solutions using the natural clinoptilolite and preparation of nano-NiO on the exhausted clinoptilolite, Applied Surface Science, 2010, 257(5), 1524-1532.

[6] Sprynskyy M., Buszewski B., Terzyk A.P., Namieśnik J. Study of the selection mechanism of heavy metal $\left(\mathrm{Pb}^{2+}, \mathrm{Cu}^{2+}, \mathrm{Ni}^{2+}\right.$, and $\left.\mathrm{Cd}^{2+}\right)$ adsorption on clinoptilolite, Journal of Colloid and Interface Science, 2006, 304(1), 21-28.

[7] Dinu M.V., Dragan E.S. Evaluation of $\mathrm{Cu}^{2+}, \mathrm{Co}^{2+}$ and $\mathrm{Ni}^{2+}$ ons removal from aqueous solution using a novel chitosan/clinoptilolite composite: Kinetics and isotherms, Chemical Engineering Journal, 2010, 160(1), 157-163.

[8] Полимеризация виниловых мономеров. Под ред. Д. Хема. М.: Мир, 1973. 311 с. [Polymerization of vinyl monomers. Pod red. D. Hema. Moscow, Mir, 1973, 311 p. (in Russian)]

[9] Лурье Ю. Ю., Рыбникова А.И. Химический анализ производственных сточных вод. М.: Химия, 1974. 336 c. [Lure Yu.Yu., Rybnikova A.I. Chemical analysis of production sewage. Moscow, Himiya, 1974, 336 p. (in Russian)]

[10] Марченко 3. Фотометрическое определение элементов. М.: Мир, 1971. 502 с. [Marchenko. Z. Photometric definition of elements. Moscow, Mir, 1971, 502 p. (in Russian)]

11] Смирнов А.Д. Сорбционная очистка воды. Л.: Химия, 1982. 168 с. [Smirnov A.D. Getter water treatment. Leningrad, Himiya, 1982, 168 p. (in Russian)] 
[12] Цивадзе А.Ю., Русанов А.И., Фомкин А.А. и др. Физическая химия адсорбционных явлений / М.: Граница, 2011. 304 с. [Civadze A.Yu., Rusanov A.I., Fomkin A.A. et all. M.: Granicza, 2011, 304 p. (in Russian)]

[13] Помазкина О.И., Филатова Е.Г., Пожидаев Ю.Н. Адсорбция катионов никеля(II) природными цеолитами. Физикохимия поверхности и защита материалов, 2014, 50(3), 262-267 [Pomazkina O.I., Filatova E.G., Pozhidaev Yu.N. Adsorption of nickel(II) cations by natural zeolites, Protection of Metals and Physical Chemistry of Surfaces, 2014, 50(3), 262-267 (in Russian)]

[14] Филатова Е.Г., Пожидаев Ю.Н., Помазкина О.И. Исследование адсорбции ионов тяжелых металлов природными алюмосиликатами. Физикохимия поверхности и защита материалов, 2016, 52(3), 285-289 [Filatova E.G., Pomazkina O.I., Pozhidaev Yu.N. Investigation of adsorption of heavy metal ions by natural aluminosilicate, Protection of Metals and Physical Chemistry of Surfaces, 2016, 52(3), 285-289 (in Russian)]

[15] Помазкина О.И., Филатова Е.Г., Пожидаев Ю.Н. Адсорбция ионов меди(II) гейландитом кальция, Физикохимия поверхности и защита материалов, 2015, 51(4), 370-374 [Pomazkina O.I., Filatova E.G., Pozhidaev Yu.N. Adsorption of copper(II) ions by calcium heulandite, Protection of Metals and Physical Chemistry of Surfaces, 2015, 51(4), 370-374 (in Russian)] 